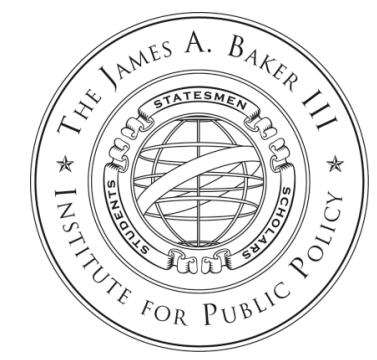

James A. Baker III Institute for Public Policy

RICE UNIVERSITY

\title{
Municipal Connectivity PRovision: SOCIETAL IMPERATIVE OR FisCAL FOLLY
}

BY

\author{
Christopher Bronk, Ph.D.
}

Fellow IN TeCHNOLOGY, SOCIETY AND Public POLICY

James A. BAKeR III InSTITUTE FOR PUblic POlicy

RICE UNIVERSITY

AND

KiRSTEN JONES

RESEARCH ASSISTANT

Technology, SocieTy and Public Policy Program

RICE UNIVERSITY

JUNE 2008 
THESE PAPERS WERE WRITTEN BY A RESEARCHER (OR RESEARCHERS) WHO PARTICIPATED IN A BAKER INSTITUTE RESEARCH PROJECT. WHEREVER FEASIBLE, THESE PAPERS ARE REVIEWED by OUTSIDE EXPERTS BEFORE THEY ARE RELEASED. HOWEVER, THE RESEARCH AND VIEWS EXPRESSED IN THESE PAPERS ARE THOSE OF THE INDIVIDUAL RESEARCHER(S), AND DO NOT NECESSARILY REPRESENT THE VIEWS OF THE JAMES A. BAKER III INSTITUTE FOR PUbLIC POLICY.

(C) 2008 by the James A. Baker III Institute for Public Policy of Rice University

THIS MATERIAL MAY BE QUOTED OR REPRODUCED WITHOUT PRIOR PERMISSION, PROVIDED APPROPRIATE CREDIT IS GIVEN TO THE AUTHOR AND

the James A. Baker III Institute for Public Policy. 
One of the most often repeated queries at the Baker Institute's "Conference on Convergence and Connectivity: Wireless, Broadband and Mobile" (CCC 2008) was the question of whether public investment in information technology (IT) infrastructure improves the economic well-being of the general population. While research tells us that there is a digital divide between those connected to the Internet and those not - largely based on capacity to pay for that connectivitywe are unsure of the ramifications of that divide. ${ }^{1}$ On what may be a well-informed hunch, many believe that connection to the Internet will improve the opportunities of those connected to it. But to what degree does academic research confirm or disprove this hunch? We may look to historical evidence regarding other communications technologies and some preliminary assessments, but our answer to the research question is not definitive.

Since the beginning of electronic communication in the mid-nineteenth century, U.S. firms have figured prominently in technological innovation and its application in commerce and government. From the telegraph and telephone to radio, television, and the Internet, communication technologies have revolutionized business activity and functions. In what may be considered the first major thrust of globalization, the telegraph connected the mercantilist empires of Europe, permitting sovereign companies to more efficiently acquire and allocate resources for industrial production. Now, more than a century later, fiber-optic and wireless telephony serve as an enabler for global management of supply chains, customer relationships, and enterprise resources across what some considered to be a "flattened planet." In studies of IT economics, we see a general consensus on the value of IT in creating new avenues of economic activity. Yet architects of public policy must determine how to invest resources into new infrastructure and applications for providing digital connectivity under conditions upon which return on investments must be visible in the near term. There is a disconnect between ideals requiring long-term investment and the cycle of technology infrastructure maturity. While it is desirable for the government to deliver public goods of a technical nature, there runs a risk that government involvement in the business of de facto service providers may lead it astray of its core roles and competencies.

\footnotetext{
${ }^{1}$ Susannah Fox, Digital Divisions (Pew Internet and American Life Project, 2005), http://www.pewinternet.org/PPF/r/165/report display.asp (accessed April 28, 2008).

${ }^{2}$ Thomas Friedman, The World Is Flat: A Brief History of the Twenty-First Century (New York: Farrar Strauss \& Giroux, 2005).
} 
Although it is the undisputed leader in development of IT infrastructure and applications, the United States is now consistently ranked lower than other developed countries in terms of broadband penetration. ${ }^{3}$ This could be because there is little incentive to build private networks in low-income areas. ${ }^{4}$ Public wireless hotspots are practically nonexistent in the low-income neighborhoods of Texas's state capital ${ }^{5}$ and many other cities. Historically, the market has failed to provide services to communities "that are either high cost (e.g., low-density rural communities where it is more costly per home passed to deploy outside plant) or economically less developed (i.e., poor)." In addition, "there may be a perceived "market failure' if the private sector fails to deliver adequate competitive alternatives in terms of the prices charged, the breadth of selection, or the quality of broadband services offered."

However, according to a report by the Information Technology \& Innovation Foundation (ITIF), the IT sector spurs unprecedented moderate- to long-term economic growth in five areas: productivity, employment, market efficiency, quality of goods and services, and innovation of new products and services. As is increasingly evident, IT pervades almost every sector of the economy. Consequently, it would be dangerous to ignore IT when constructing policy. The ITIF recommends "five key principles policymakers around the globe should follow if their nations are to fully benefit from the digital revolution." One of these is particularly relevant to municipal wireless initiatives: "Encourage Universal Digital Literacy and Digital Technology Adoption." In other words, it supports lessening the digital divide by providing access to technology and teaching citizens how to use it. According to the ITIF, "Ensuring that we take full advantage of the IT revolution will require that a large majority of citizens participate in the digital economy" through activities such as paying bills online. ${ }^{8}$

\footnotetext{
${ }^{3}$ Michael Botein, "Regulation of Municipal Wi-Fi," New York School Law Review 51 (2006): 977.

${ }^{4}$ Andrea Tapia et al., "Making IT work for municipalities: Building municipal wireless networks," Government Information Quarterly 23 (2006): 376.

${ }^{5}$ Martha Fuentes-Bautista and Nobuya Inagaki, "Reconfiguring public Internet access in Austin, TX: Wi-Fi's promise and broadband's divides," Government Information Quarterly 23 (2006): 431.

${ }^{6}$ Lehr et al., "Wireless is changing the policy calculus for municipal broadband," Government Information Quarterly 23 (2006): 439.

${ }^{7}$ Lehr et al., "Wireless is changing the policy calculus for municipal broadband," Government Information Quarterly 23 (2006): 439.

${ }^{8}$ Robert D. Atkinson and Andrew S. McKay, "Digital Prosperity: Understanding the Economic Benefits of the Information Technology Revolution,” The Information Technology \& Innovation Foundation 2007: 1 - 6.
} 


\section{Municipal Connectivity Provision}

Many scholars agree that broadband can promote economic development. ${ }^{9}$ Their research may be divided into studies of municipal wireless networks, wireless networks in general, all broadband services, and the entire IT sector. Studies show that municipal wireless networks may offer a way for cities "to both strengthen the economy by attracting new tech firms and drive down the cost of broadband access so all residents can connect to the Internet." ${ }^{\prime 10}$ Municipal wireless networks may also be used to deliver city services more efficiently and thereby "maximize the value of the taxpayer's dollar." In addition, they may be used as a vehicle for equitable access because they are able to pull more consumers into the digital economy. ${ }^{12}$ Finally, they can promote local economic development by lowering barriers to entry for wireless Internet providers, which ensures "the availability of broadband services that have become essential to many forms of economic activity." ${ }^{, 13}$ Problems arise, however, with regard to implementation cost and scaling. For example, Tempe, Arizona, and Blacksburg, Virginia, are both home to large state universities and have successfully deployed municipal Wi-Fi networks, though Tempe's network shut down earlier this year. Larger cities, such as Chicago, Houston, and even technological center San Francisco have faced significant obstacles in deploying comprehensive municipal wireless networks. Vendors for the networks have simply found themselves unable to deliver the service while generating revenue able to sustain business activity.

\footnotetext{
${ }^{9}$ Alison Powell and Leslie Regan Shade, "Going Wi-Fi in Canada: Municipal and community initiatives," Government Information Quarterly 23 (2006): 386-388;

Scott A. Shamp, "Wi-Fi Clouds and Zones: A Survey of Municipal Wireless Initiatives," Mobile Media Consortium, The New Media Institute, University of Georgia 2004: 3;

Sharon E. Gillett, "Municipal Wireless Broadband: Hype or Harbinger?" Southern California Law Review 79 (2006): 584-590;

Kristin Van Gaasbeck et al., "Economic Effects of Increased Broadband Use in California," Sacramento Regional Research Institute 2007: 1;

John Windhausen Jr., "A Blueprint for Big Broadband,” EDUCAUSE 2008: ii;

Andrea Tapia et al., "Making IT work for municipalities: Building municipal wireless networks," Government Information Quarterly 23 (2006): 371;

James Gibbons and Steve Ruth, “Municipal Wi-Fi: Big Wave or Wipeout?" IEEE Internet Computing May/June 2006: 69.

${ }^{10}$ Andrea Tapia et al., "Making IT work for municipalities: Building municipal wireless networks," Government Information Quarterly 23 (2006): 371.

${ }^{11}$ Sharon E. Gillett, "Municipal Wireless Broadband: Hype or Harbinger?" Southern California Law Review 79 (2006): 590.

${ }^{12}$ Sharon E. Gillett, “Municipal Wireless Broadband: Hype or Harbinger?" Southern California Law Review 79 (2006): 590.

${ }^{13}$ Sharon E. Gillett, "Municipal Wireless Broadband: Hype or Harbinger?" Southern California Law Review 79 (2006): 590.
} 
Powell and Shade suggest that wireless networks, including private, municipal, and community initiatives, generally spur economic development through tourism-related uses. ${ }^{14}$ An example of such a network is a wireless zone - an "aggregation of cooperating hotspots sharing a single management system." ${ }^{\prime 15}$ Cooperating point-of-presence hotspots are often retail establishments frequented by visitors to the city. As a result, the overwhelming majority of wireless zones target tourists and business travelers. ${ }^{16}$ But providing business travelers with Wi-Fi connectivity while moving is challenging, because "to make Wi-Fi networking an everyday tool for road warriors, as commonplace as their cell phones, major enhancements to existing Wi-Fi technology are required."17 Wi-Fi remains an immature technology and potential information security concerns may slow its adoption by big business.

General broadband availability and use also has been linked with economic development. ${ }^{18}$ According to a January 2008 EDUCAUSE white paper, "The availability of broadband capability would generate enormous economic activity (both from building the network and from its use) that would lead to greater tax revenue and economic growth."19 This is consistent with previous findings by other researchers. After mounting an analysis of actual broadband use and economic growth, the Sacramento Regional Research Institute found that "increased broadband use (and migration from dial-up to broadband access) within California has had a positive effect on employment and payroll growth." ${ }^{20}$ In addition, a study commissioned by the Department of Commerce linked broadband availability in communities in 1999 to "a one percent higher rate of job growth from 1998-2002," as compared to communities without broadband. ${ }^{21}$ One might

\footnotetext{
${ }^{14}$ Alison Powell and Leslie Regan Shade, "Going Wi-Fi in Canada: Municipal and community initiatives," Government Information Quarterly 23 (2006): 386-388.

${ }^{15}$ Scott A. Shamp, "Wi-Fi Clouds and Zones: A Survey of Municipal Wireless Initiatives," Mobile Media Consortium, The New Media Institute, University of Georgia 2004: 3.

${ }^{16}$ Scott A. Shamp, "Wi-Fi Clouds and Zones: A Survey of Municipal Wireless Initiatives," Mobile Media Consortium, The New Media Institute, University of Georgia 2004: 4.

${ }^{17}$ Paul S. Henry and Hui Luo, "WiFi: What's Next?" IEEE Communications Magazine December 2002: 66.

${ }^{18}$ John Windhausen Jr., "A Blueprint for Big Broadband,” EDUCAUSE 2008: ii;

Kristin Van Gaasbeck et al., "Economic Effects of Increased Broadband Use in California," Sacramento Regional Research Institute 2007: 1;

Sharon E. Gillett, "Municipal Wireless Broadband: Hype or Harbinger?" Southern California Law Review 79 (2006): 584.

${ }^{19}$ John Windhausen Jr., “A Blueprint for Big Broadband,” EDUCAUSE 2008: ii.

${ }^{20}$ Kristin Van Gaasbeck et al., "Economic Effects of Increased Broadband Use in California," Sacramento Regional Research Institute 2007: 1.

${ }^{21}$ Sharon E. Gillett, "Municipal Wireless Broadband: Hype or Harbinger?" Southern California Law Review 79 (2006): 584.
} 
hypothesize that the economic gains attributed to general broadband availability and use would also appear when access is provided by a municipal wireless initiative in the form of a publicprivate partnership.

The problem and promise for municipal efforts in the Wi-Fi arena is in the multiple issues governments are tasked to address. The role of wireless connectivity in serving the municipal government is straightforward. Police officers, sanitation managers, and surveyors would no doubt be aided by ubiquitous mobile broadband connectivity as they do their work. Building a network to serve this purpose is politically feasible, but does not present the rosiest of returns on investment; the municipal work force in even the largest cities will probably consume only a small portion of the available bandwidth. Adding in the digital inclusion piece, marking the objective that connectivity to the Internet should be available to all, allocates the remaining bandwidth, but places the municipality in direct competition with regulated providers. Although this may create a competitive force for lowering broadband pricing, it may also cause providers to flee at times when they recapitalize their infrastructure.

The model for provision of broadband connectivity, be it wireless or wired, is subject to debate, as open-market competition, regulated monopoly, and municipally provided options run against the problem of convergence. With telephone, Internet, televised entertainment, and other services now employing a variety of delivery mechanisms, from copper wire and coaxial cable to fiber optic links and wireless technology, disparate services such as cable television and telephone now compete. As a result, municipalities are left to choose from a variety of business models in which ownership and operation of the network ranges from completely public to completely private. $^{22}$

The question of whether or not municipal investment in public-use digital network infrastructure can spur economic development is intricately interwoven with two related factors: state-level regulation of services and the municipalities' selection of a service model. Several states, including Texas, have considered placing restrictions on the development of municipal wireless

\footnotetext{
${ }^{22}$ Andrea Tapia et al., "Making IT work for municipalities: Building municipal wireless networks," Government Information Quarterly 23 (2006): 374-377.
} 


\section{Municipal Connectivity Provision}

networks on the grounds that such networks would impede free market competition. ${ }^{23}$ However, studies on the impact of municipal entry on the broadband market yield inconclusive results. ${ }^{24}$ Legislative activity by commercial telecommunications providers is designed to provide the optimum conditions to recoup their investment in building out infrastructure. This advocacy, in turn, limits the capacity of municipalities to construct infrastructure. ${ }^{25}$

Perhaps the desirable path to pursue is one in which the government buys the services it needs for municipal functions and provides a subsidy designed to bring additional competition into the broadband market while serving those not currently purchasing broadband services. This may produce payoffs in stimulating innovative new entrants in the market and permitting smaller niche players to pursue unmet sectors. Also, government sponsored awareness campaigns patterned on the model of ConnectKentucky may spur demand. ${ }^{26}$ If demand cannot be stimulated via subsidy and heightened awareness at the national level, then we will hold solid evidence that FCC Chairman Michael Powell, who argued that some Americans merely choose not to pay for access to the Internet at market prices, ${ }^{27}$ may have been right in his beliefs regarding the digital divide.

Underlying any discussion on government initiatives to provide Internet access to a greater number of households or to subsidize the development of higher-bandwidth connections are value judgments on the government's role in providing or subsidizing access. Building out networks is an expensive activity. Verizon's Fiber Optic Service (FiOS), which will deliver highend broadband conenctivity to some 18 million customers by 2010, will likely cost the company $\$ 23$ billion. $^{28}$ With pricing for the service varying between $\$ 40$ and \$200 per month, customers

\footnotetext{
${ }^{23}$ Andrea Tapia et al., "Making IT work for municipalities: Building municipal wireless networks," Government Information Quarterly 23 (2006): 365. Bills in this area cover everything from utility pole access and compensation (2007 Illinois H.B. 4120, 95th General Assembly, House Bill 4120) to free access to wireless Internet at Louisiana's state tourist welcome centers (2008 Louisiana H.B. 1189, 2008 Regular Legislative Session, House Bill 1189).

${ }^{24}$ Lehr et al., "Wireless is changing the policy calculus for municipal broadband," Government Information Quarterly 23 (2006): 451.

${ }^{25}$ Andrea Tapia et al., "Making IT work for municipalities: Building municipal wireless networks," Government Information Quarterly 23 (2006): 365.

${ }^{26}$ Connected Nation, Inc., The Economic Impact of Stimulating Broadband Nationally (2008), http://www.connectednation.com/economic impact_study/ (accessed April 28, 2008).

${ }^{27}$ Labaton, Stephen, "New F.C.C. Chief Would Curb Agency Reach," New York Times, February 7, 2001.

${ }^{28}$ Mehta, Stephanie, "Verizon's big bet on fiber optics," Fortune, February 22, 2007, http://money.cnn.com/magazines/fortune/fortune archive/2007/03/05/8401289/ (accessed April 29, 2008).
} 
buying the more expensive, high-end service packages will help the company recoup their more than $\$ 1,275$ per customer startup investment. To sell to customers at a $\$ 200$ price allows the company to pay off their initial investment, minus operating cost, in about six months. A $\$ 10$ user cost, similar to that proposed by various municipal Wi-Fi initiatives, would draw that interval out to more than ten years. The question then is this: Does the government pick up the other part of the tab? In the current fiscal climate, the likely answer is no.

Turning to the policymaker, what advice can be given? There are several trends upon which to guide thinking. First, our notion of what constitutes broadband is changing. The large quantity of "dark fiber" 29 laying unused in the United States at the beginning of the decade is now increasingly employed, delivering data to users desirous of high-bandwidth services. But while the City of Houston attempts to deploy 500 kilobit per second Wi-Fi bubbles, Japan's NTTDoCoMo mobile service is working to field a 250 Megabit per second wireless network. ${ }^{30}$ This network would theoretically be able to deliver about 500 times the data in the same period as Houston's proposed plan. With the potential for massive breakthroughs in wireless technology, knowing what Wi-Fi technology to buy and when to buy it becomes an issue. Second, the computer hardware upon which we base our notions of the digital divide is changing. ${ }^{31}$ We need look no farther than Japan again to see a likely outcome eventually to be replicated here in the United States. While younger Japanese consumers continue to buy increasingly expensive video gaming consoles and $3 \mathrm{G}^{32}$ mobile phone devices, they are not replacing their personal computers. ${ }^{33}$ More and more, digital convergence is occurring on small, mobile devices rather than PCs. Public investment in IT infrastructure failing to recognize these developments will likely see limited efficacy over a shorter than optimal timeline.

While we do not have a full understanding of how Wi-Fi or broadband access to all sectors of society impacts overall economic activity, we can accept some important lessons learned several

\footnotetext{
${ }^{29}$ Fiber optic cable emplaced during the 1990s but largely underutilized until bandwidth demand grew.

${ }^{30}$ Richard Thurston, "Tokyo 250Mbps mobile supernetwork speeds into life," The Register, March 27, 2008, http://www.theregister.co.uk/2008/03/27/massive tokyo network/ (accessed April 28, 2008).

${ }^{31}$ John Markoff, “Intel Makes a Push Into Pocket-Size Internet Devices,” New York Times, April 2, 2008, http://www.nytimes.com/2008/04/02/technology/02chip.html (accessed April 28, 2008).

32 3G: Third generation wireless device.

${ }^{33}$ Faiola, Anthony, "In Japan, a wireless vision of future for U.S.," MSNBC, http://www.msnbc.msn.com/id/4306834/ (accessed April 29, 2008).
} 
years into municipal experiments with ubiquitous computing. No large city in the United States has deployed a seamless wireless Internet cloud, largely because no clear model has yet emerged for making Internet connectivity available to many for free. At the same time, large connectivity providers fail to deliver to all segments of society, simply because not all citizens are willing to pay for a service of questionable utility. Service providers balk at municipal network building as government competition with their often heavily regulated businesses. Using tax dollars to compete with major corporations seems a misallocation of public funds, but if there is insufficient demand to form a market, then competition can never truly exist. Government's creation of a marketplace where one is not desired, does not fit its mandate. One thing is certain: any up front investment in IT infrastructure, whether wireless, wired, or other, will also require long term allocation of resources for maintenance, repair, and overhaul. While it is generally accepted that Moore's Law and related phenomena push down the price of microprocessor driven networking hardware, the labor costs for those technicians needed to monitor and upgrade the network continue to rise. Simply put, any municipal infrastructure buy in the IT area is a down payment and carries considerable costs to be borne over the life cycle of the system.

The search for remedies to market failure in the broadband service sector leads down the road of solutions provided by policy rather than industry. Ultimately, the rhetorical device used to explain what should be done is the public-private partnership, a term that invokes Pareto optimal outcomes, but that may actually be a positive window dressing for government-industry compromise. As demonstrated in the policy literature, public-private partnerships may spur innovation and competition, ${ }^{34}$ as well as lessen the digital divide by providing access for lowincome areas. ${ }^{35}$ By ensuring ubiquitous access, municipalities can move toward a state of affairs in which they contribute to further growth in the IT sector at their own benefit. ${ }^{36}$

Scholarship regarding public-private partnerships in the provision of connectivity services is not inconsiderable. According to Gibbons and Ruth, cities offering broadband through public-

\footnotetext{
${ }^{34}$ Sharon E. Gillett, “Municipal Wireless Broadband: Hype or Harbinger?” Southern California Law Review 79 (2006): 592.

${ }^{35}$ Andrea Tapia et al., "Making IT work for municipalities: Building municipal wireless networks," Government Information Quarterly 23 (2006): 379.

${ }^{36}$ Robert D. Atkinson and Andrew S. McKay, "Digital Prosperity: Understanding the Economic Benefits of the Information Technology Revolution,” The Information Technology \& Innovation Foundation 2007: 6.
} 
private partnerships tend to do better than those using exclusively public or private business models. ${ }^{37}$ This may be true outside the United States as well: One research team found that "public-private partnerships in Canada appear to be mutually advantageous." ${ }^{" 38}$ Perhaps the success of these models can be attributed to the one researcher's finding that, "If properly structured ... such partnerships can in fact encourage private sector competition, innovation, and investment, not "crowd it out." "'39 Municipal wireless initiatives "provide an important forum for experimentation with novel communications technologies and business models," which "is essential to the dynamic health of the U.S. economy." 40 A wide variety of public-private partnership business models may be viewed as potential tools with which to address telecommunications companies and state legislatures in an effort to ease legislative barriers to municipal entry. ${ }^{41}$ Experimentation and selective tweaking in the balance between public and private activity and responsibility may be the best route to determining viable paths to progress.

\footnotetext{
${ }^{37}$ James Gibbons and Steve Ruth, "Municipal Wi-Fi: Big Wave or Wipeout?” IEEE Internet Computing May/June 2006: 68.

${ }^{38}$ Alison Powell and Leslie Regan Shade, "Going Wi-Fi in Canada: Municipal and community initiatives," Government Information Quarterly 23 (2006): 401.

${ }^{39}$ Sharon E. Gillett, "Municipal Wireless Broadband: Hype or Harbinger?" Southern California Law Review 79 (2006): 592.

${ }^{40}$ Sharon E. Gillett, "Municipal Wireless Broadband: Hype or Harbinger?" Southern California Law Review 79 (2006): 565.

${ }^{41}$ Andrea Tapia et al., "Making IT work for municipalities: Building municipal wireless networks," Government Information Quarterly 23 (2006): 379-380.
} 